University of South Florida

DIGITAL COMMONS

Digital Commons @ University of

@ UNIVERSITY OF SOUTH FLORIDA

South Florida

USF Tampa Graduate Theses and Dissertations

USF Graduate Theses and Dissertations

January 2013

\title{
The Effects of Video Self-Evaluation on Skill Acquisition with Yoga Postures
}

Holly Elizabeth Downs

University of South Florida, hedowns@mail.usf.edu

Follow this and additional works at: https://digitalcommons.usf.edu/etd

Part of the Behavioral Disciplines and Activities Commons

\section{Scholar Commons Citation}

Downs, Holly Elizabeth, "The Effects of Video Self-Evaluation on Skill Acquisition with Yoga Postures" (2013). USF Tampa Graduate Theses and Dissertations.

https://digitalcommons.usf.edu/etd/4885

This Thesis is brought to you for free and open access by the USF Graduate Theses and Dissertations at Digital Commons @ University of South Florida. It has been accepted for inclusion in USF Tampa Graduate Theses and Dissertations by an authorized administrator of Digital Commons @ University of South Florida. For more information, please contact digitalcommons@usf.edu. 
The Effects of Video Self-Evaluation on Skill Acquisition with Yoga Postures

by

Holly E. Downs

\begin{abstract}
A thesis submitted in partial fulfillment
of the requirements for the degree of Master of Arts

Department of Child and Family Studies

College of Behavioral and Community Sciences

University of South Florida
\end{abstract}

Major Professor: Raymond Miltenberger, Ph.D.

Kimberly A. Crosland, Ph.D.

Lisa Witherspoon, Ph.D.

Date of Approval:

October 24, 2013

Keywords: self-monitoring, video feedback, sports, fitness, yoga

Copyright @ 2013, Holly E. Downs 


\section{Table of Contents}

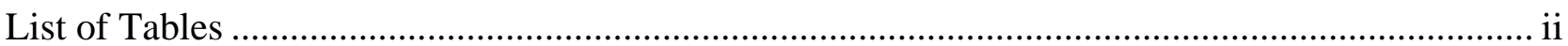

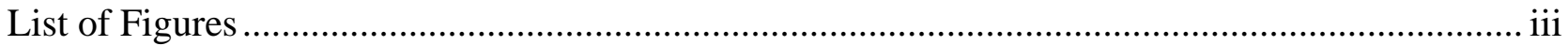

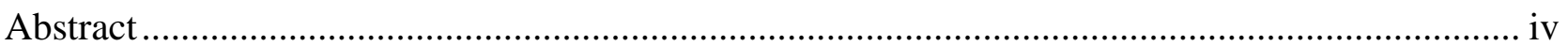

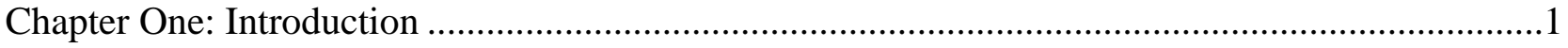

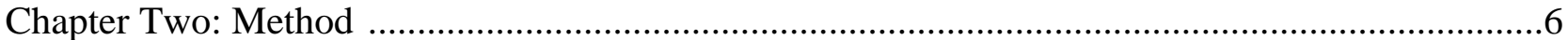

Participants and Setting..................................................................................................6

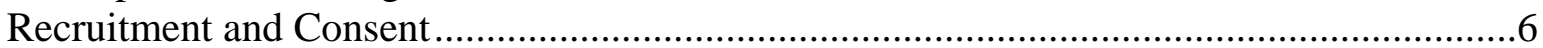

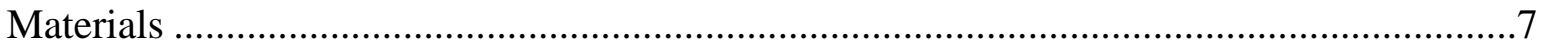

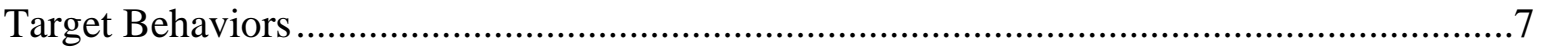

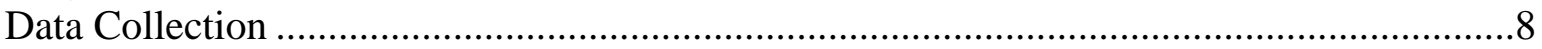

Inter-observer Agreement ................................................................................................

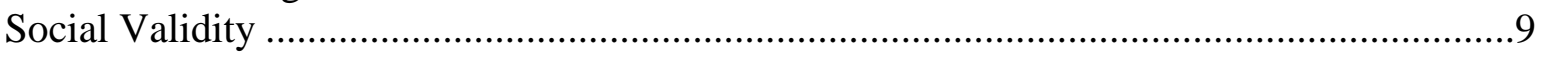

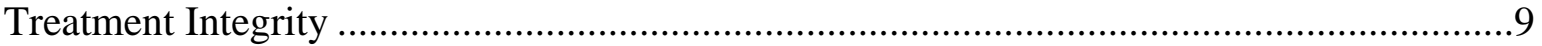

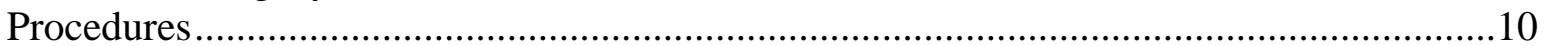

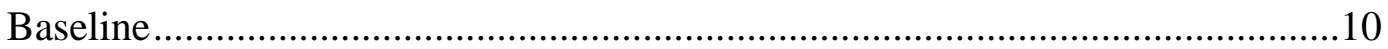

Video self-evaluation (VSE) ...............................................................................11

Video feedback ……….................................................................................11

Maintenance ...............................................................................................12

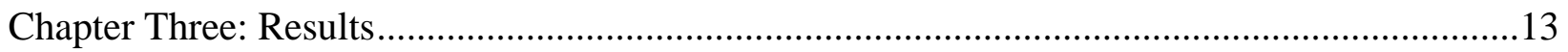

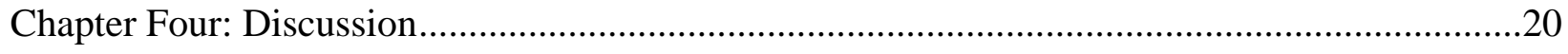

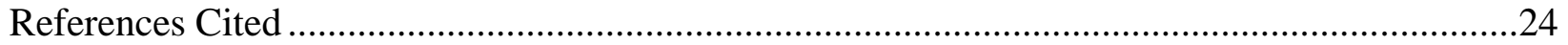

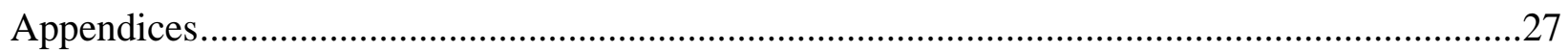

Appendix A: Task Analysis for the Virabhadrasana II.......................................................28

Appendix B: Task Analysis for the Svanasana................................................................29

Appendix C: Task Analysis for the Vriksasana .................................................................30

Appendix D: Instructor Rating Scale..............................................................................31

Appendix E: Participant Social Validity Scales..................................................................32

Appendix F: Observer Rating Scales ................................................................................34 


\section{List of Tables}

Table 1: $\quad$ Mean Social Validity Ratings of Video Self-evaluation for Bill and Ted..............15

Table 2: $\quad$ Social Validity Rating of Video Feedback for Ted ..................................................15

Table 3: $\quad$ Mean Instructor Ratings for the Svanasana Pose for Bill .......................................15

Table 4: $\quad$ Mean Instructor Ratings for the Vriksasana Pose for Bill ......................................16

Table 5: $\quad$ Mean Instructor Ratings for the Virabhadrasana Pose for Bill................................16

Table 6: $\quad$ Mean Instructor Ratings for the Svanasana Pose for Ted.......................................17

Table 7: $\quad$ Mean Instructor Ratings for the Vriksasana Pose for Ted......................................17

Table 8: $\quad$ Mean Instructor Ratings for the Virabhadrasana Pose for Ted.................................17 


\section{List of Figures}

Figure 1: $\quad$ Percentage Correct on Task Analyses Across Sessions for Bill ..........................18

Figure 2: $\quad$ Percentage Correct on Task Analyses Across Sessions for Ted..........................19 


\begin{abstract}
This study evaluated the use of video self-evaluation and video feedback procedures to enhance the accuracy of yoga poses. In the self-evaluation intervention participants watched their behaviors via video and scored task analyses for feedback for each pose. In the video feedback intervention, the participants and the researcher together scored the task analyses for the behaviors along with practice during video recordings. The interventions were assessed in a multiple baseline across behaviors design. Results showed that both video self-evaluation increased the accuracy of all poses and video feedback further increased the accuracy on one pose for one participant.
\end{abstract}




\section{Chapter One: Introduction}

Recently there has been much hype in the western media concerning injuries related to yoga (e.g., Alvarez, 2010; Fishman, Saltonstall, \& Genis, 2009). Yoga is an ancient practice dating back thousands of years in the eastern hemisphere, and recently the art has weaved its way into the western culture (Alvarez, 2010). There are many different areas of practice with yoga. One of the most popular forms in the western culture is hatha yoga which is generally comprised of breathing exercises, various postures, and meditation (Tran, Holly, Lashbrook, \& Amsterdam, 2001). Generally yoga classes involve an instructor that acts as a model and presents verbal feedback while students practice various positions. Classes may involve a group of people or individualized instruction.

Numerous health benefits for persons practicing yoga are identified not only by the media, but by empirical literature as well (e.g., Fishman et al., 2009; Tran et al., 2001). Ross and Thomas (2010) conducted a literature review of various studies regarding yoga's effects on health. The studies assessed the effects of yoga versus other forms of exercise (e.g., stationary cycling, walking, and jogging) on several health outcomes. When they compared the different studies, they found yoga to be more effective than the other forms of exercise measured in 22 out of 32 health components including menopausal symptoms, kidney function, sleep disturbance, cholesterol levels, and fatigue. Nearly $70 \%$ of the literature assessed found yoga to be more beneficial than other exercises with the various health conditions. These results show that yoga may have a more positive effect on health conditions when practiced regularly than other forms of exercise. The famous New York Times article, "When Yoga Hurts,” discussed the potential 
harmful effects of practicing yoga (Alvarez, 2010). The article discussed that many people get hurt in yoga classes because they may not warm up or stretch before engaging in the activities. The article makes the point because American yoga classes are so large it is often difficult to get feedback on various poses. One can use an online search engine to search "yoga injuries” and find millions of related websites and blogs. Researchers conducted an international survey and from the results they found that one of the four most reported causes of injury with yoga was "inadequate or improper instructions being given to students" (Fishman et al., 2009, p. 51). The western culture is beginning to have the same viewpoint as the media: practicing yoga can cause injuries just like any other sport or fitness activity (Alvarez, 2010). With the growing number of people looking to yoga as a form of exercise, it is important for behavior analysts to evaluate procedures to improve yoga practice and thus prevent injuries from happening.

Various procedures have been evaluated to promote skill acquisition and productivity in sports and fitness (e.g., Allison \& Ayllon, 1980; Hume \& Crossman, 1992; Osborne, Rudrud, \& Zezoney, 1990). Some interventions have included coaching packages (e.g., Allison \& Ayllon, 1980; Komaki \& Barnett, 1977), the introduction of visual cues (Osborne et al., 1990), contingent musical reinforcement (Hume \& Crossman, 1992), attentional shift training (Ziegler, 1994), goal setting and public goal posting (e.g., Smith \& Ward, 2006; Ward \& Carnes, 2002), TAGteach training (e.g., Fogel, Weil, \& Burris, 2010; Stokes, Luiselli, Reed, \& Fleming, 2010), and video modeling and feedback (e.g., Boyer, Miltenberger, Batsche, \& Fogel, 2009; Guadagnoli, Holcomb, \& Davis, 2002; Rikli \& Smith, 1980).

One procedure that has been proven to be effective for skill acquisition in a variety of areas is the use of video (Dowrick, 1991). The use of video could increase the amount of instructor or self-monitored feedback. Procedures used to increase feedback are important 
because limited feedback is a major problem as class sizes for yoga training continue to grow (Alvarez, 2010). Procedures used to increase feedback could also increase skill acquisition while decreasing the number of injuries associated with practicing yoga. An efficient and cost effective method of giving feedback on performance is using video (Dowrick, 1991). The use of video has been assessed in various areas of research including, but not limited to: sports (e.g., Benitezsantiago \& Miltenberger, 2012; Rikli \& Smith, 1980; Stokes et al., 2010), peer interactions (e.g., Dunlap et al., 1992; Maione \& Mirenda, 2006), and preventing injury in workstations (e.g., Nielsen, Sigurdsson, \& Austin, 2009; Sigurdsson \& Austin, 2008).

Video modeling has been used in combination with video feedback and has been shown to have a significant effect on behavior measured in various studies (e.g., Boyer et al., 2009; Nielsen et al., 2009; Zetou, Tzetzis, Vernadakies, \& Kioumourtzoglou, 2002). Zetou et al. (2002) assessed video procedures on acquisition and retention of the form of set and serve volleyball skills in a group design. One group used video modeling with verbal cues from instructors and the second group received verbal feedback while watching the videos of their own behaviors. The results showed higher skill acquisition with the expert modeling than with the self-modeling group. Boyer et al. (2009) examined the effectiveness of a video treatment package including modeling and feedback on the acquisition of three gymnastic skills in a multiple baseline across behaviors design. There was a clear increase in skill set acquisition with the introduction of the video treatment package. Nielsen et al. (2009) evaluated a procedure in which the participants scored the video models and were given feedback on the scores. The study evaluated the effectiveness of video modeling and feedback procedures for increasing safe and correct patient lifting transfers by staff in a multiple baseline across participants design. With the introduction of video modeling the percentage of correct lifting by all participants 
except for one increased, and for the two participants that were given the feedback phase, the percentage correct increased to even higher levels.

Another element frequently used in combination with video feedback is instructional feedback (e.g., Guadagnoli et al., 2002; Rikli \& Smith, 1980; Stokes et al., 2010). Guadagnoli et al. (2002) evaluated the effectiveness of video feedback, verbal feedback, and self-guided feedback for a golf swing in a pretest-posttest randomized group design. The self-guided group participants were instructed to practice on their own. The verbal feedback group participants were trained with an expert and given verbal feedback on their swings. The video feedback group was paired with an expert that provided verbal feedback and video feedback throughout the training sessions. The results indicated that the introduction of video feedback had the greatest effect on the distance and accuracy of the golf swing of participants. Stokes et al. (2010) evaluated the effectiveness of verbal feedback and video plus verbal feedback for increasing football blocking skills in a multiple baseline across participants design. With descriptive feedback alone, the correct number of steps in the task analysis did not increase. With the introduction of the video feedback procedure, the percentage of correct steps increased substantially. In another recent study, Benitezsantiago and Miltenberger (2012) evaluated two video feedback procedures for improving skills related to capoeira, a performance style of martial arts. In the video feedback phase, participants watched their performance on the video as the researcher provided feedback, and during the video feedback plus practice phase participants practiced the movements two to five times before being videotaped and given live feedback from the instructor. Their results showed that the video feedback condition improved skills to greater percentages quicker than typical practice for all three movements measured, and skills increased to higher percentages with the introduction of practice sessions between videotaping. 
Several video feedback interventions involve a self-evaluation element (e.g., Boyer et al., 2009; Guadagnoli et al., 2002). Self-evaluation procedures have been shown to have considerable effects on behaviors (Dunlap et al., 1992; Sigurdsson \& Austin, 2008). Selfevaluation procedures can be valuable for instructors with larger class sizes who might not have time to provide feedback to all the students. Dunlap et al. (1992) evaluated the effects of an intervention that included a video self-evaluation procedure for increasing desirable peer interactions in children with severe emotional and behavioral disabilities. Students watched themselves on video, identified desirable behaviors, and received reinforcers for correct selfevaluation and desirable behaviors. With the introduction of the intervention, desirable behavior increased for all participants. Sigurdsson and Austin (2008) assessed the effectiveness of a realtime video feedback procedure combined with a self-monitoring procedure for increasing safe postures for participants working at desks. In the video plus self-monitoring phase, participants observed their own postures on video and scored them as safe or unsafe while attending to a typing task. The results showed an increase in correct posturing for the participants.

Because of the national concern with yoga injuries in the media and the general public (e.g., Alvarez, 2010), it is important for behavior analysts to evaluate procedures for enhancing skill acquisition and reducing injuries. The implementation of a video feedback procedure may increase these skill sets more rapidly and to a greater extent than the traditional style of instruction, and the use of self-evaluation may increase the utility of the procedure. There were two purposes to the study. Firstly, the study assessed a video self-evaluation (VSE) procedure to enhance the skills involved in practicing yoga. Secondly, if the VSE procedure was not effective the study evaluated the use of a standard video feedback procedure, much like the one used by Benitezsantiago and Miltenberger (2012). 


\section{Chapter Two: Method}

\section{Participants and Setting}

The study included two participants, ages 21 (Bill) and 24 (Ted) who responded to a flyer describing the study. The participants were interested in learning yoga poses, did not have experience in yoga, and did not have any injuries. Both participants were students of a university and attended classes on the university campus. The experimental procedure was conducted in a fitness lab at the physical education department on the university campus.

Bill attended the university as a student of computer engineering, and was interested in the study because he wanted to begin a fitness program. Bill had little experience with fitness overall, and stated that since he had experience with meditation, yoga would be a good fitness exercise for him. Bill also stated that he did not exercise or practice yoga outside of the sessions. Ted attended the university as a anthropology major, and was interested in the study because he wanted to attend yoga classes with more knowledge on the basic poses. Ted showed interest in several poses, and stated that he would like to include the intervention with the other poses. While in the study, Ted played various sports and was active outside of the sessions.

\section{Recruitment and Consent}

The researcher posted flyers on the university campus and the adults interested in the study were given information via email. All adults interested in the study received handouts regarding the intervention and were asked if they wanted to participate. The adults who agreed to participate met with the researcher and signed consent forms. 


\section{Materials}

The materials included one Canon T3i digital single-lens video camera, a tripod, an Acer laptop, itunes video playing software for direct immediate feedback, and yoga mats for the participants' use. A memory card from the camera was inserted into the laptop computer to decrease the latency of feedback after the target behaviors were exhibited. The video camera recorded the participants' flow of poses. The tripod held the camera in place and decreased any shaking or human error while recording the participants. The laptop and video playing software were utilized for assessment, video self-evaluation and video feedback. The participants were encouraged to use the yoga mats for exhibiting the poses.

\section{Target Behaviors}

Target behaviors were comprised of task analyses of three common yoga poses (see Appendices A-C for the three yoga poses). The poses were chosen based on the low probability that the acquisition of one pose would influence the acquisition of another pose. The poses were also chosen because they are generally introduced in a typical beginning yoga class (Cleveland Clinic, n.d.). The three yoga instructors working with the researchers agreed that the poses chosen for measurement were appropriate for beginner level yoga students and for healthy individuals.

The poses included the vriksasana (tree pose), the virabhadrasana II (warrior pose two), and the svanasana (downward facing dog pose). The vriksasana is a balancing pose in yoga where one stands on one leg with arms raised. The virabhadrasana II is a stretch pose where one stands with legs and arms spread apart. The svanasana is a stretch pose where one stands on the hands and feet. The task analyses developed by the researcher were reviewed by a certified yoga instructor who judged the task analyses to accurately depict the steps involved in each pose. 


\section{Data Collection}

For each phase the participants’ behaviors were recorded via video camera and scored by the researchers using the task analyses. To ensure the best scoring and the best feedback, the participants were recorded at different angles depending upon the pose being assessed.

Vriksasana and virabhadrasana II were recorded from the front of the participants. Svanasana was recorded from the side of the participants. Behaviors in the task analyses for each pose were coded by the researcher as either correct or incorrect during assessment sessions. The percentage correct was calculated by dividing the number of correct steps by the number of steps in the task analysis multiplied by $100 \%$.

\section{Inter-observer Agreement}

Thirty-three percent of video recording sessions were observed by two independent observers. A total inter-observer agreement (IOA) method was calculated across each phase for every behavior. Each observer independently watched and scored the videos of the participants

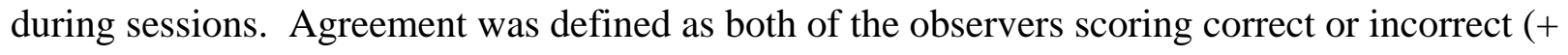
or -) for the same step within the task analyses. The percentage of agreement for each task analysis was calculated by dividing the number agreements by the number of agreements plus disagreements (steps in the task analysis) multiplied by 100\%.

The mean IOA for both participants was 95.9\% (range $=86 \%-100 \%$ ). For Bill, the mean IOA across behaviors for the baseline phase was $95.9 \%$ with a mean of $93 \%$ for vriksasana, a mean of $98.3 \%$ for svanasana, and a mean of $95.9 \%$ for virabhadrasana II. The mean IOA across behaviors for the treatment phase was $94.5 \%$ with a mean of $96.5 \%$ for vriksasana, a mean of 95\% for svanasana, and a mean of $93.3 \%$ for virabhadrasana II. For Ted, the mean IOA across behaviors for the baseline phase was $96.4 \%$ with a mean of $100 \%$ for vriksasana, a mean of 
$100 \%$ for svanasana, and a mean of $93.3 \%$ for virabhadrasana II. The mean IOA across behaviors for the treatment phase was $96.7 \%$ with a mean of $95.6 \%$ for vriksasana, a mean of 97.1\% for svanasana, and a mean of $97.8 \%$ for virabhadrasana II.

\section{Social Validity}

Three questionnaires assessed the social validity of the target behaviors for the intervention and the outcome of the experiment. A certified yoga instructor approved the task analyses of the three poses to socially validate the behaviors measured. The instructor gave open-ended feedback on the task analyses, and the researchers edited the task analyses based on the feedback given. The instructor followed up on the final edit of the task analyses by rating them on a 5-point Likert-type scale (see Appendix D). Participants received one of two questionnaires in the form of a rating scale (see Appendix E) regarding the ease of participation and acceptability of the intervention. All participants were asked to fill out a 5-point Likert-type scale to assess the social validity of the intervention. The participant exposed to the video feedback phase of the intervention received the questionnaires for both the video-feedback and self-evaluation interventions, whereas the participant only exposed to the VSE intervention received the questionnaire only relating to the self-evaluation intervention.

Another aspect of social validity included the assessment of the outcome of each phase by observers blind to each experimental condition, similar to that of the Boyer et al. (2009) study. Two certified yoga instructors scored a sample of the videos in random order of phases. The observers were asked to score the videos on a 5-point Likert-type scale (see Appendix F).

\section{Treatment Integrity}

To assess treatment integrity, a percentage of agreement was scored between the researcher and participant on the task analyses as the participant conducted the video self- 
evaluation. The percentage was calculated by dividing the number agreements by the number of agreements plus disagreements multiplied by $100 \%$. The percentage of agreement between the researcher and participant assessed the skill acquisition and procedural integrity of each participant during both experimental phases of the intervention.

Treatment integrity data were collected for at least $50 \%$ of sessions for Bill, and at least $40 \%$ of sessions for Ted. When treatment integrity fell below $80 \%$, the researcher retrained the participants to utilize the task analysis while watching the videos. Treatment integrity fell below 80\% once with Bill, and twice with Ted. The mean treatment integrity across sessions for Bill was $89 \%$, with a range of $67 \%-100 \%$. The mean treatment integrity across sessions for Ted was $91 \%$, with a range of $66 \%-100 \%$.

\section{Procedures}

A multiple baseline across behaviors research design was used to assess the intervention effects with each participant's yoga poses. Data were collected on the participants' poses throughout baseline, VSE, and maintenance phases. A video feedback condition was implemented for one pose. One to three assessment sessions were conducted in each meeting of the researchers and participants, and at least one meeting per week was conducted throughout the experiment.

Baseline. Data for participants' poses were collected while the participants used standard procedures for yoga. The researcher acted as a model throughout the first two sessions of the baseline phase, much like that of standard yoga instruction. The participants were told to continue using the standard procedures for practicing yoga throughout baseline. The participants attempted each pose two to three times during each assessment session. 
Video self-evaluation (VSE). In this phase, the participants viewed their pose on video immediately after participating in the pose and evaluated the pose by using the task analysis to score each of the steps in the pose. The intervention was first applied to one pose until increases were observed in that pose and then applied to the other two poses in sequence. The first two sessions of the VSE phase for each pose involved the researcher showing the participants how to evaluate each video by using the task analyses. The researcher viewed the video with the participants, scored the behaviors with the participants via the task analysis data sheet, and discussed the scoring of correct or incorrect steps observed. Each subsequent session in this phase consisted of the participants scoring each video without assistance or feedback. During this phase the participants practiced each pose individually, and subsequently watched the video recording of the practice. While watching the recording, the participants scored themselves as correct or incorrect on the various steps that constructed each pose. The researcher was not present in the room during the self-evaluation of the videos. The researchers separately scored the video and calculated the percentage of agreement to assess treatment integrity of each participant.

Video feedback. The video feedback phase was implemented if a high level of skill acquisition did not occur throughout the VSE phase. The video feedback phase was implemented with one pose during the intervention condition. During the video feedback intervention phase the researcher video recorded the participant practicing the pose. The participant then watched the practice video as the researcher provided feedback on each step in the task analysis. The participant practiced the pose again and immediately watched the video as the researcher provided verbal feedback. 
Maintenance. To assess maintenance of the procedures, participants were video recorded at 2 weeks (Ted) and 5 weeks (Bill) following the removal of the intervention. The researchers then scored the videos of the participants’ poses with the task analyses. 


\section{Chapter Three: Results}

The introduction of VSE resulted in an immediate increase in the percentage correct for

all six asanas across two participants. Results are shown in Figures 1 and 2. For one asana that did not increase to high levels for Ted, VSE and video feedback procedures resulted in a substantial increase in the asana. The experimental procedures were introduced following the introduction to the standard yoga instruction procedures, and as expected, some skill acquisition occurred in the longer baseline phases.

Because there were increasing trends in some of the baseline phases, the researchers measured two baseline means much like that of Boyer et al. (2009). The researchers measured whole baseline and end of baseline means. The end of baseline mean was calculated on the portion of the data that was stable at the end of the baseline phase. The means for the interventions were also calculated on the portion of the data that was stable and the end of the intervention phases.

As shown in Figure 1, VSE was effective for Bill's three poses. For the vriksasana pose, the whole baseline mean was $17 \%$, and the mean of the last six data points of the VSE intervention was $96 \%$. For the svanasana pose, the end of baseline mean of $37 \%$, and the mean for the last six data points of VSE was 73\%. For the virabhadrasana II pose, the end of baseline mean was 48\%, and the VSE intervention mean was 87\%. During the maintenance assessment for Bill, the percentage correct for each pose decreased to $57 \%$ for the vriksasana pose, 55\% for the svanasana pose, and 60\% for the virabhadrasana II pose. 
As shown in Figure 2, VSE was effective for two of Ted's poses and VSE and video feedback were effective for a third pose. For the svanasana pose, the whole baseline mean was $13 \%$, the VSE phase mean was $48 \%$, and the video feedback phase mean was $95 \%$. For the vriksasana pose, the whole baseline mean was $29 \%$, and mean of for the last seven data points of VSE was $98 \%$. For the virabhadrasana II pose, the end of baseline mean was 55\%, and the mean for VSE was $86 \%$. During the maintenance assessment, the percentage correct for each pose was $84 \%$ for the vriksasana pose, $90 \%$ for the svanasana pose, and $80 \%$ for the virabhadrasana II pose.

Social validity data for the participants' acceptance of the interventions are shown on Tables 1 and 2. Table 1 shows the social validity results for the VSE procedure, and Table 2 shows the results for the video feedback procedure. Bill felt comfortable practicing the vriksasana and virabhadrasana II poses, but was not comfortable practicing the svanasana pose. Even though Bill stated that the accuracy of his poses increased after VSE, he stated that he did not like the procedure. Ted stated that he felt comfortable practicing each pose and he enjoyed both the VSE and video feedback procedures. Ted stated that he felt the accuracy of his poses increased after being introduced to the procedures.

A yoga instructor rated the task analyses that were used to measure the behaviors with high scores, suggesting that the task analyses were a valid depiction of the yoga poses. Instructor social validity data from blind ratings of performance in baseline and intervention phases showed that the instructors agreed that the VSE and video-feedback procedures produced noticeable changes in the yoga poses. Overall, the yoga instructors rated the poses higher in the intervention phases than in baseline (Tables 3-8). For Bill, the average rating from the instructors for baseline and intervention was 2.5 and 3.5 for the svanasana pose, 1.8 and 3.8 for 
the vriksasana pose, and 2.4 and 4.0 for the virabhadrasana II pose. For Ted, the average rating from the instructors for baseline and intervention was 3.0 and 3.8 for the svanasana pose, 3.3 and 3.9 for the vriksasana pose, and 3.0 and 3.8 for the virabhadrasana II pose..

Table 1. Mean Social Validity Ratings of Video Self-evaluation for Bill and Ted

\begin{tabular}{|l|l|l|l|l|l|l|}
\hline & & $\begin{array}{l}\text { Strongly } \\
\text { Disagree }\end{array}$ & Disagree & Neutral & \multicolumn{1}{|c|}{ Agree } & $\begin{array}{c}\text { Strongly } \\
\text { Agree }\end{array}$ \\
\hline 1. & $\begin{array}{l}\text { I am comfortable performing the } \\
\text { Virabhadrasana II (Warrior II pose). }\end{array}$ & & & & 2 & \\
\hline 2. & $\begin{array}{l}\text { I am comfortable performing the } \\
\text { Vriksasana (Tree pose). }\end{array}$ & & & & 1 & 1 \\
\hline 3. & $\begin{array}{l}\text { I am comfortable performing the } \\
\text { Svanasana (Downward Facing Dog } \\
\text { pose). }\end{array}$ & 1 & & & & 1 \\
\hline 4. & $\begin{array}{l}\text { I liked using video feedback and the task } \\
\text { analyses to self-manage my poses. }\end{array}$ & 1 & & & 1 & 1 \\
\hline 5. & $\begin{array}{l}\text { I think my poses got better after using } \\
\text { video feedback. }\end{array}$ & & & 1 & 1 & \\
\hline 6. & $\begin{array}{l}\text { The video feedback took the same } \\
\text { amount of time that I expected. }\end{array}$ & & 1 & & & 1 \\
\hline
\end{tabular}

Table 2. Social Validity Rating of Video Feedback for Ted

\begin{tabular}{|c|c|c|c|c|c|c|}
\hline & & $\begin{array}{l}\text { Strongly } \\
\text { Disagree }\end{array}$ & Disagree & Neutral & Agree & $\begin{array}{c}\text { Strongly } \\
\text { Agree }\end{array}$ \\
\hline 1. & $\begin{array}{l}\text { I am comfortable performing the } \\
\text { Virabhadrasana II (Warrior II pose). }\end{array}$ & & & & 1 & \\
\hline 2. & $\begin{array}{l}\text { I am comfortable performing the } \\
\text { Vriksasana (Tree pose). }\end{array}$ & & & & & 1 \\
\hline 3. & $\begin{array}{l}\text { I am comfortable performing the } \\
\text { Svanasana (Downward Facing Dog } \\
\text { pose). }\end{array}$ & & & & & 1 \\
\hline 4. & I liked using video feedback. & & & & 1 & \\
\hline 5. & $\begin{array}{l}\text { I think my poses got better after using } \\
\text { video feedback. }\end{array}$ & & & & & 1 \\
\hline 6. & $\begin{array}{l}\text { The video feedback took the same } \\
\text { amount of time that I expected. }\end{array}$ & & & 1 & & \\
\hline
\end{tabular}

Table 3. Mean Instructor Ratings for the Svanasana Pose for Bill

\begin{tabular}{|l|l|l|l|}
\hline & \multicolumn{1}{|c|}{ Baseline } & \multicolumn{1}{|c|}{ VSE } \\
\hline 1. & $\begin{array}{l}\text { The participant performed the Svanasana (Downward Facing Dog } \\
\text { pose) with high accuracy. }\end{array}$ & 1.5 & 3.25 \\
\hline 2. & $\begin{array}{l}\text { The participant looked like an expert when performing the } \\
\text { Svanasana (Downward Facing Dog pose). }\end{array}$ & 1.75 & 3.25 \\
\hline
\end{tabular}


Table 3 (Continued)

\begin{tabular}{|l|l|l|l|}
\hline & \multicolumn{1}{|c|}{ Baseline } & \multicolumn{1}{|c|}{ VSE } \\
\hline 3. & $\begin{array}{l}\text { The participant seemed to understand the flow of the Svanasana } \\
\text { (Downward Facing Dog pose) }\end{array}$ & 2 & 3.25 \\
\hline 4. & $\begin{array}{l}\text { The participant's body parts were in the correct places during the } \\
\text { flow of the Svanasana (Downward Facing Dog pose). }\end{array}$ & 2.25 & 3.5 \\
\hline 5. & The participant began the pose in the correct position. & 2.75 & 3.75 \\
\hline 6. & The participant ended the pose in the correct position. & 2 & 3.75 \\
\hline
\end{tabular}

Table 4. Mean Instructor Ratings for the Vriksasana Pose for Bill

\begin{tabular}{|l|l|l|l|}
\hline & \multicolumn{1}{|c|}{ VSE } & \multicolumn{1}{|c|}{} \\
\hline 1. & $\begin{array}{l}\text { The participant performed theVriksasana (Tree pose) with high } \\
\text { accuracy. }\end{array}$ & 1.75 & 3.5 \\
\hline 2. & $\begin{array}{l}\text { The participant looked like an expert when performing the } \\
\text { Vriksasana (Tree pose) }\end{array}$ & 1.5 & 3.5 \\
\hline 3. & $\begin{array}{l}\text { The participant seemed to understand the flow of the Vriksasana } \\
\text { (Tree pose). }\end{array}$ & 1.5 & 4.25 \\
\hline 4. & $\begin{array}{l}\text { The participant's body parts were in the correct places during the } \\
\text { flow of the Vriksasana (Tree pose). }\end{array}$ & 1.75 & 4 \\
\hline 5. & $\begin{array}{l}\text { The participant began the pose in the correct position. } \\
6 .\end{array}$ & The participant ended the pose in the correct position. & 2.5 \\
\hline
\end{tabular}

Table 5. Mean Instructor Ratings for the Virabhadrasana Pose for Bill

\begin{tabular}{|l|l|l|l|}
\hline & \multicolumn{1}{|c|}{ VSE } & \multicolumn{1}{|c|}{} \\
\hline 1. & $\begin{array}{l}\text { The participant performed the Virabhadrasana II (Warrior II pose) } \\
\text { with high accuracy. }\end{array}$ & 2.25 & 4 \\
\hline 2. & $\begin{array}{l}\text { The participant looked like an expert when performing the } \\
\text { Virabhadrasana II (Warrior II pose). }\end{array}$ & 2 & 3.5 \\
\hline 3. & $\begin{array}{l}\text { The participant seemed to understand the flow of the } \\
\text { Virabhadrasana II (Warrior II pose). }\end{array}$ & 2.5 & 4 \\
\hline 4. & $\begin{array}{l}\text { The participant's body parts were in the correct places during the } \\
\text { flow of the Virabhadrasana II (Warrior II pose). }\end{array}$ & 2.5 & 4.5 \\
\hline 5. & $\begin{array}{l}\text { The participant began the pose in the correct position. } \\
6 .\end{array}$ & The participant ended the pose in the correct position. & 2.75 \\
\hline
\end{tabular}


Table 6. Mean Instructor Ratings for the Svanasana Pose for Ted

\begin{tabular}{|c|c|c|c|}
\hline & & Baseline & VSE \\
\hline 1. & $\begin{array}{l}\text { The participant performed the Svanasana (Downward Facing Dog } \\
\text { pose) with high accuracy. }\end{array}$ & 2 & 3.75 \\
\hline 2. & $\begin{array}{l}\text { The participant looked like an expert when performing the } \\
\text { Svanasana (Downward Facing Dog pose). }\end{array}$ & 1.75 & 3.25 \\
\hline 3. & $\begin{array}{l}\text { The participant seemed to understand the flow of the Svanasana } \\
\text { (Downward Facing Dog pose). }\end{array}$ & 2.75 & 4 \\
\hline 4. & $\begin{array}{l}\text { The participant's body parts were in the correct places during the } \\
\text { flow of the Svanasana (Downward Facing Dog pose). }\end{array}$ & 2 & 3.75 \\
\hline 5. & The participant began the pose in the correct position. & 3.75 & 4.25 \\
\hline 6. & The participant ended the pose in the correct position. & 3 & 4 \\
\hline
\end{tabular}

Table 7. Mean Instructor Ratings for the Virksasana Pose for Ted

\begin{tabular}{|c|c|c|c|}
\hline & & Baseline & VSE \\
\hline 1. & $\begin{array}{l}\text { The participant performed the Vriksasana (Tree pose) with high } \\
\text { accuracy. }\end{array}$ & 2.75 & 3.75 \\
\hline 2. & $\begin{array}{l}\text { The participant looked like an expert when performing the } \\
\text { Vriksasana (Tree pose). }\end{array}$ & 2.5 & 3.75 \\
\hline 3. & $\begin{array}{l}\text { The participant seemed to understand the flow of the Vriksasana } \\
\text { (Tree pose). }\end{array}$ & 3.25 & 4 \\
\hline 4. & $\begin{array}{l}\text { The participant's body parts were in the correct places during the } \\
\text { flow of the Vriksasana (Tree pose). }\end{array}$ & 3 & 3.75 \\
\hline 5. & The participant began the pose in the correct position. & 3.5 & 4.25 \\
\hline 6. & The participant ended the pose in the correct position. & 3 & 3.75 \\
\hline
\end{tabular}

Table 8. Mean Instructor Ratings for the Virabhadrasana Pose for Ted

\begin{tabular}{|c|c|c|c|}
\hline & & Baseline & VSE \\
\hline 1. & $\begin{array}{l}\text { The participant performed the Virabhadrasana II (Warrior II pose) } \\
\text { with high accuracy. }\end{array}$ & 1.75 & 4 \\
\hline 2. & $\begin{array}{l}\text { The participant looked like an expert when performing the } \\
\text { Virabhadrasana II (Warrior II pose). }\end{array}$ & 1.75 & 3.25 \\
\hline 3. & $\begin{array}{l}\text { The participant seemed to understand the flow of the } \\
\text { Virabhadrasana II (Warrior II pose). }\end{array}$ & 1.75 & 4 \\
\hline 4. & $\begin{array}{l}\text { The participant's body parts were in the correct places during the } \\
\text { flow of the Virabhadrasana II (Warrior II pose). }\end{array}$ & 2.25 & 4 \\
\hline 5. & The participant began the pose in the correct position. & 2.5 & 4.25 \\
\hline 6. & The participant ended the pose in the correct position. & 2 & 3.5 \\
\hline
\end{tabular}




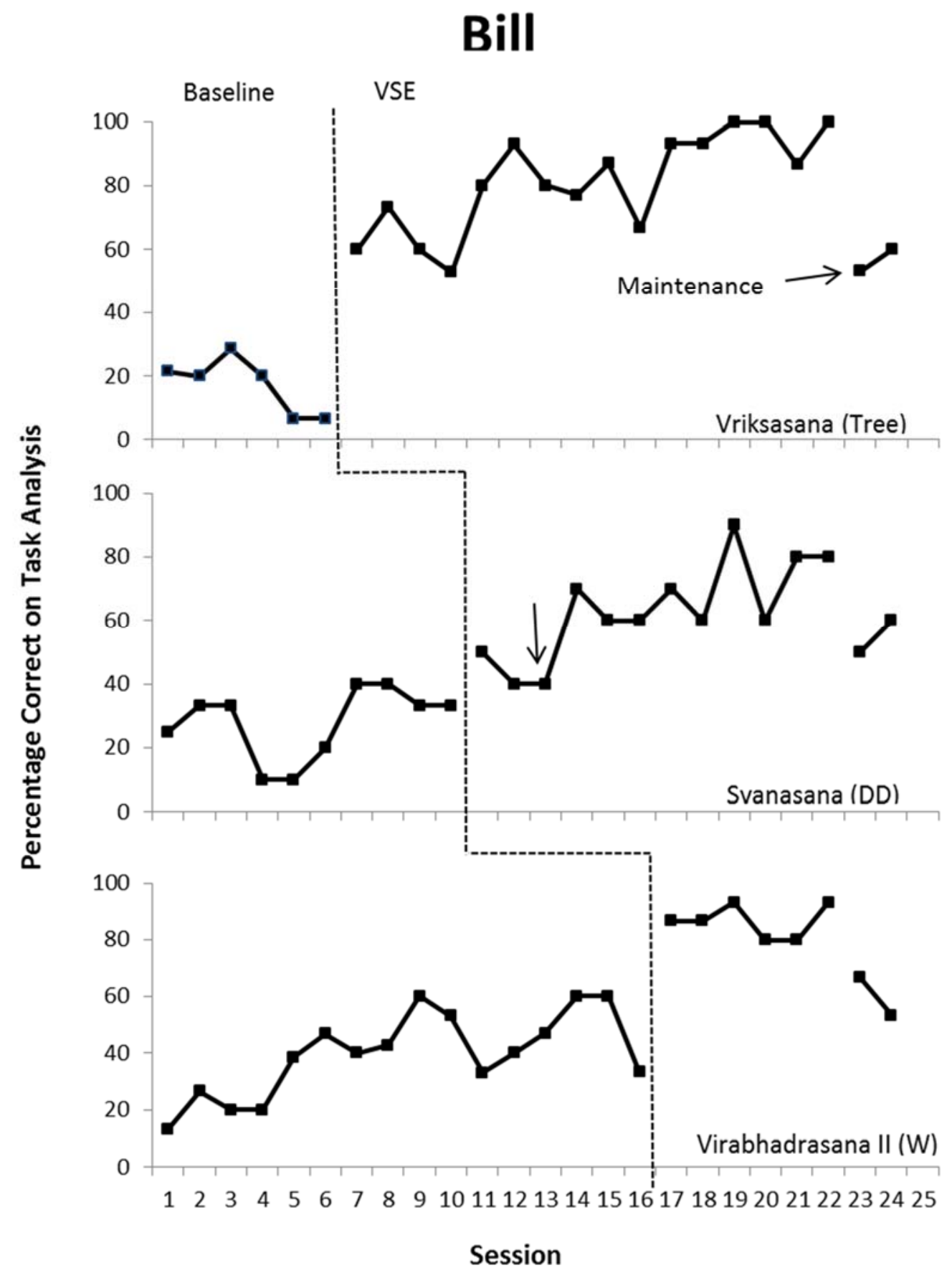

Figure 1. Percentage Correct on Task Analyses Across Sessions for Bill. The above graph shows the percentage correct of Bill's vriksasana, svanasana, and virabhadrasana II poses. The unmarked arrow represents the session where retraining occurred. 


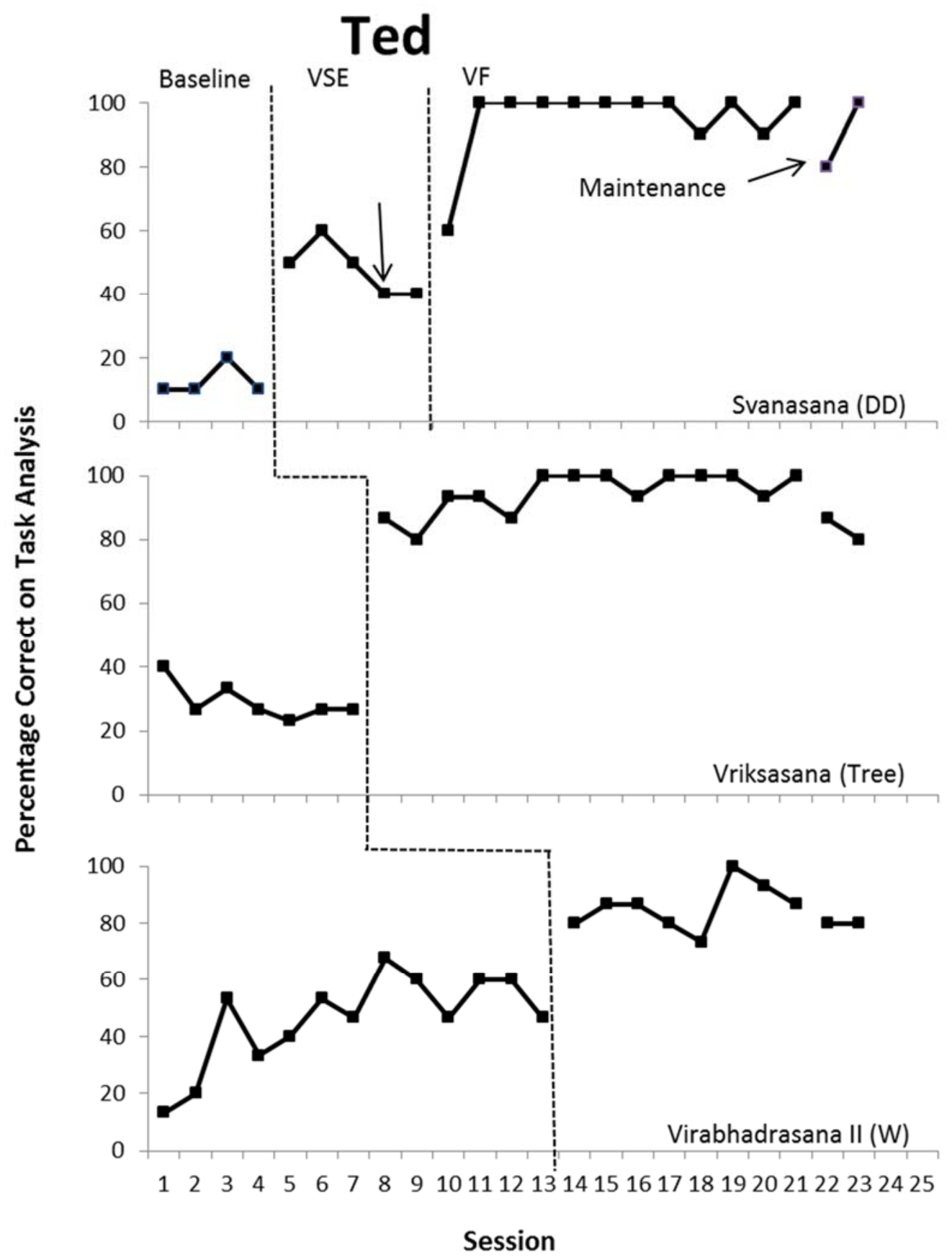

Figure 2. Percentage Correct on Task Analyses Across Sessions for Ted. The graph above shows the percentage correct of Ted's svanasana, vriksasana, virabhadrasana II poses. The unmarked arrow represents the session where retraining occurred. 


\section{Chapter Four: Discussion}

The study assessed the effectiveness of a video self-evaluation (VSE) procedure with three yoga poses for two participants, and video-feedback was evaluated with one pose. The VSE procedure increased the percentage correct with all of the poses, and the video-feedback procedure increased performance of one pose for one participant even further. VSE can be utilized for persons who are not receiving the amount of feedback from an instructor necessary to increase correct performance and prevent injury. With the VSE procedure, a yoga practitioner in a class could videorecord him or herself practicing a pose and then immediately review the recording for self evaluation. The findings in this study suggest that such an approach can lead to substantial increases in performance regardless of fitness level. One participant in the study did not engage in fitness activities while the other was active in athletic activities, and both showed acquisition for the poses measured with the introduction of the intervention.

Furthermore, such a procedure could be conducted with little disruption to the class. The results of this study are comparable to those of studies evaluating similar procedures including self-monitoring and self-evaluation from video (Dunlap et al., 1992) and video feedback with self-evaluation (Sigurdsson \& Austin, 2008). This study provides more evidence that individuals can evaluate their own performance via video to increase performance. Furthermore, the increases in performance in the current study are comparable to results obtained in studies using video feedback from the researchers (Benitezsantiago \& Miltenberger, 2013; Boyer et al., 2009) suggesting that VSE might be a viable alternative to traditional video feedback that requires a 
coach or other expert to review the video with an athlete and provide feedback as the video recording is being reviewed. Although these results were positive, more research is needed to substantiate the findings.

Personal preference for the intervention, reflected in the social validity questionnaires completed by the participants, varied between participants. Bill stated that he did not like the procedure; however Ted stated that he enjoyed it. During the baseline phase for both participants, there was a low level of performance for each of the three skills. For Bill, VSE greatly increased his performance of both the vriksasana and virabhadrasana II poses. For his svanasana pose, there was increased performance although not as elevated as the other poses. For Ted, VSE increased his performance of all three poses; however his performance of the svanasana pose was not as high as anticipated. Video-feedback increased his execution of the svanasana pose to a greater extent than did the VSE procedure.

Although the data indicated that VSE can be an effective procedure for increasing yoga, some limitations were also noted. Finding beginner level volunteers proved more problematic than anticipated and, because the participants were unfamiliar with yoga, they appeared challenged with the notion of failure to perform with fidelity. Bill expressed dissatisfaction with his performance during the procedure until he showed higher performance of the skill. Another limitation to the study involves the maintenance data with Bill. He did not practice the poses outside of the sessions, and the maintenance data were collected 5 weeks following the end of the intervention. Lastly, both participants were retrained for self-evaluation because of low treatment integrity. The fact that the participants needed retraining on a skill suggests that video self-evaluation may not always be successful and may require a coach or researcher to evaluate the quality of the self-evaluation and provide retraining if needed. It is not clear how effective 
VSE would be without the initial training or the booster training when used by other athletes for yoga or other sports. More research should evaluate the necessary amount of preliminary training required for success and the factors that may contribute to the need for booster training.

The study was the first to assess a video self-evaluation procedure with yoga. The selfevaluation component of the procedure can increase the utility of video feedback for yoga students by limiting the amount of trainer time necessary for success. Because this study was conducted with two participants, future research should replicate the VSE procedure with other novice yoga practitioners and other yoga poses. In addition, it would be advantageous to evaluate this procedure with advanced yoga students to see if the VSE procedure can elevate performance even higher. Furthermore, future research should evaluate the effectiveness of VSE for enhancing performance in other sports. If a sport requires skilled performance and the performance can be captured on video, VSE has the potential to enhance performance. Finally, due to the findings that the video-feedback intervention was needed for one pose, future research should continue to evaluate video-feedback with yoga poses and compare its effects to the effects of VSE with yoga and other sports performance.

One variable this study did not evaluate or manipulate is motivation. Video feedback or VSE can be effective procedures if increases in performance function as reinforcers for the individual using the procedures. In this case 'motivation” might be defined as being present when improvements in performance function as reinforcers. The assumption behind video feedback and VSE in particular, is that improvements with the use of the procedure will be reinforcing, thus leading to continued high levels of performance and continued use of the procedures that produce better performance. Using the task analysis to mark the steps that were performed correctly during VSE and video feedback allowed the participant to more easily 
observe improvements in performance (i. e., to see more steps checked as correct). This immediate feedback is a key element of VSE, one that will only contribute to its success if improvements function as reinforcers (the athlete using it is "motivated”). Future research should evaluate the influence of motivation on the effectiveness of VSE, video feedback, and other behavioral procedures to enhance sports performance. 


\section{References Cited}

Allison, M.G., \& Ayllon, T. (1980). Behavioral coaching in the development of skills in football, gymnastics, and tennis. Journal of Applied Behavior Analysis, 13, 297-314.

Alvarez, L. (2010). When yoga hurts. New York Times. Retrieved from http://cityroom.blogs.nytimes.com/2010/07/24/24stretch/

Benitezsantiago, A., \& Miltenberger, R.G. (2012). Using video feedback to improve martial-arts performance. Manuscript submitted for publication.

Boyer, E., Miltenberger, R.G., Batsche, C., \& Fogel, V. (2009). Video modeling by experts with video feedback to enhance gymnastic skills. Journal of Applied Behavior Analysis, 42, 855-860.

Cleveland Clinic. (n.d.). 5 yoga poses for beginners. Retreived from http://portals.clevelandclinic.org/Portals/113/Education/FitTalks/Mindfulness\%20\&\%20 Exercise\%20Handout.pdf

Dowrick, P. W. (1991). Practical guide to using video in the behavioral sciences. New York, NY: Jon Wiley \& Sons, Inc.

Dunlap, L. K., Dunlap, G., Clarke, S., Childs, K.E., White, R.L., \& Stewart, M. P. (1992). Effects of a videotape feedback package on the peer interactions of children with serious behavioral and emotional challenges. Journal of Applied Behavior Analysis, 25, 355-364.

Fishman, L.M., Saltonstall, E., \& Genis, S. (2009). Understanding and preventing yoga injuries. International Journal of Yoga Therapy, 19, 47-53. 
Fogel, V.A., Weil, T.M., \& Burris, H. (2010). Evaluating the efficacy of tagteach as a training strategy for teaching a golf swing. Journal of Behavioral Health and Medicine, 1, 25-41.

Guadagnoli, M., Holcomb, W., \& Davis, M. (2002). The efficacy of video feedback for learning the golf swing. Journal of Sports Sciences, 20, 615-622.

Hume, K.M., \& Crossman, J. (1992). Musical reinforcement of practice behaviors among competitive swimmers. Journal of Applied Behavior Analysis, 25, 665-670.

Komaki, J., \& Barnett, F.T. (1977). A behavioral approach to coaching football: Improving the play execution of the offensive backfield on a youth football team. Journal of Applied Behavior Analysis, 10, 657-664.

Maione, L., \& Mirenda, P. (2006). Effects of video modeling and video feedback on peerdirected social language skills of a child with autism. Journal of Positive Behavior Interventions, 8, 106-118.

Nielsen, D., Sigurdsson, S.O., \& Austin, J. (2009). Preventing back injuries in hospital settings: The effects of video modeling on safe patient lifting by nurses. Journal of Applied Behavior Analysis, 42, 551-561.

Osborne, K., Rudrud, E., \& Zezoney, F. (1990). Improved curveball hitting through the enhancement of visual cues. Journal of Applied Behavior Analysis, 23, 371-377.

Rikli, R., \& Smith, G. (1980). Videotape feedback effects on tennis serving form. Perceptual and Motor Skills, 50, 895-901.

Sigurdsson, S.O., \& Austin, J. (2008). Using real-time visual feedback to improve posture at computer workstations. Journal of Applied Behavior Analysis, 41, 365-375.

Smith, S.L., \& Ward, P. (2006). Behavioral interventions to improve performance in collegiate football. Journal of Applied Behavior Analysis, 39, 385-391. 
Stokes, J.V., Luiselli, J.K., Reed, D.D., \& Fleming, R.K. (2010). Behavioral coaching to improve offensive line pass-blocking skills of high school football athletes. Journal of Applied Behavior Analysis, 43, 463-472.

Tran, M.D., Holly, R.G., Lashbrook, J., \& Amsterdam, E.A. (2001). Effects of hatha yoga on the health-related aspects of physical fitness. Preventive Cardiology, 7, 165-170.

Ward, P., \& Carnes, M. (2002). Effects of posting self-set goals on collegiate football players’ skill execution during practice and games. Journal of Applied Behavior Analysis, 35, 112.

Zetou, E., Tzetzis, G., Vernadakies, N., \& Kioumourtzoglou, E. (2002). Modeling in learning two volleyball skills. Perceptual and Motor Skills, 94, 1131-1142.

Ziegler, S.G. (1994). The effects of attentional shift training on the execution of soccer skills: A preliminary investigation. Journal of Applied Behavior Analysis, 27, 545-552. 


\section{Appendices}




\section{Appendix A: Task Analysis for the Virabhadrasana II}

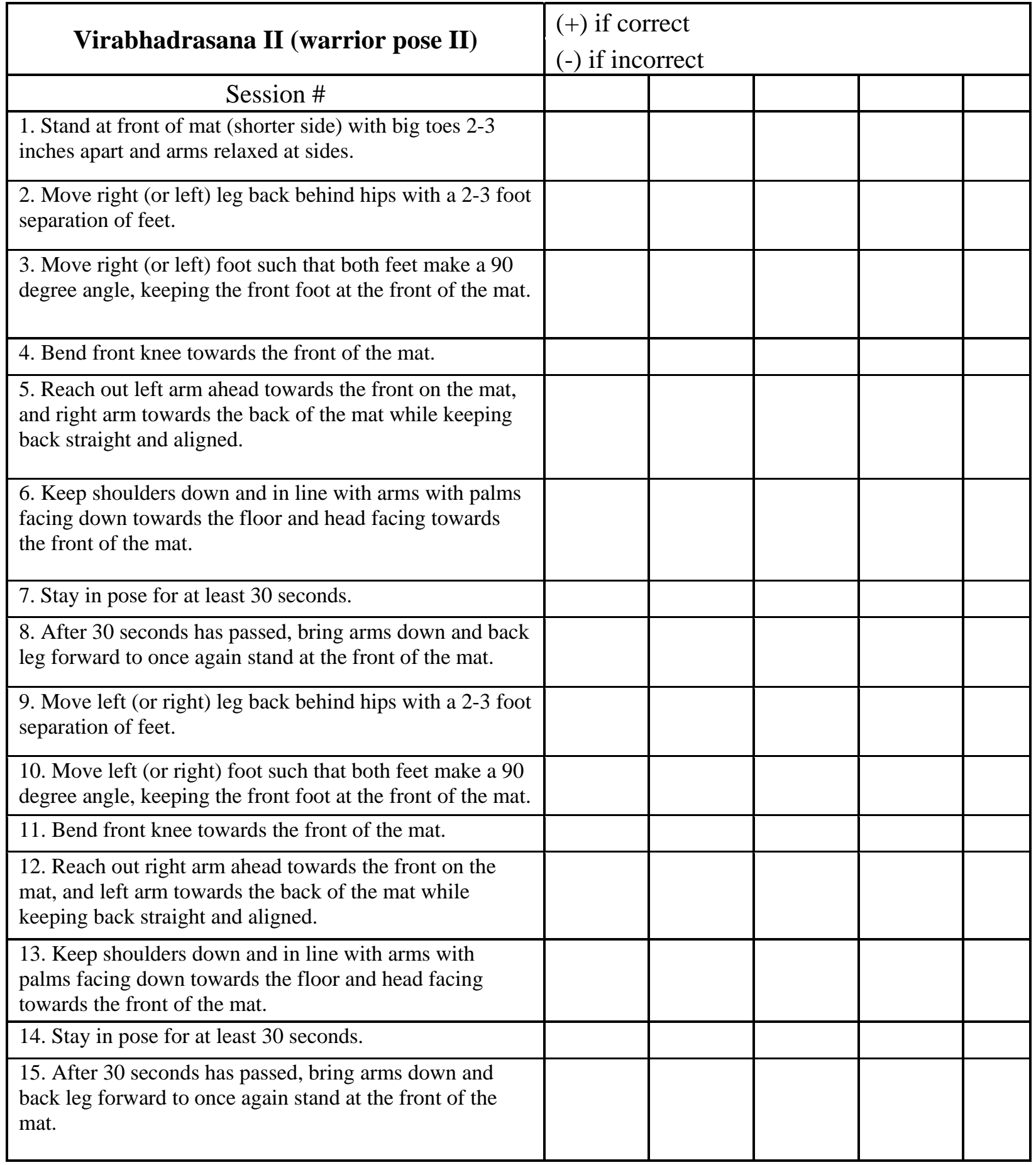




\section{Appendix B: Task Analysis for the Svanasana}

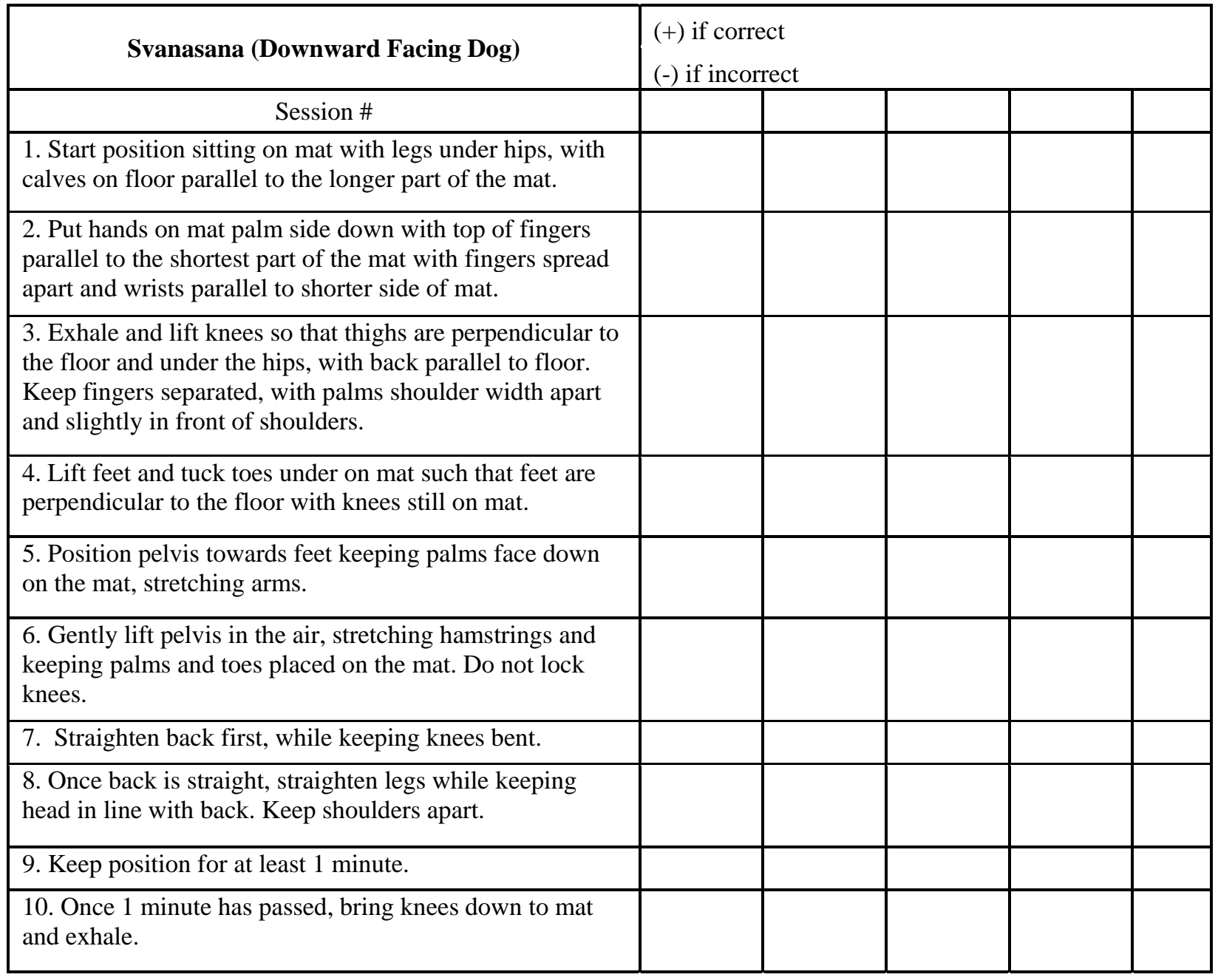




\section{Appendix C: Task Analysis for the Vriksasana}

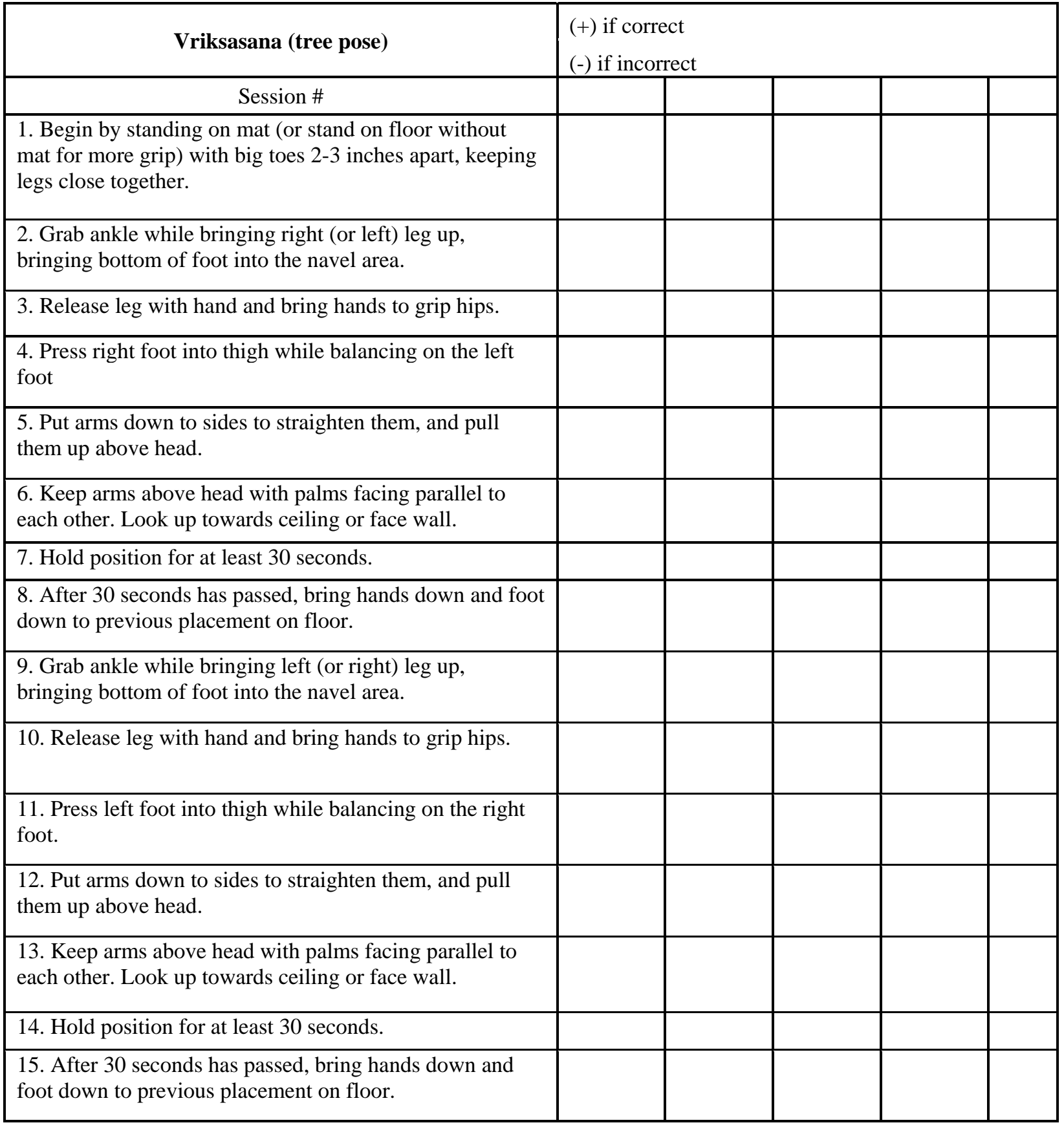




\section{Appendix D: Instructor Rating Scale}

Instructor Task Analyses Rating

Please carefully read and answer the five questions. Please make an $\mathbf{X}$ mark on the line that best indicates your opinion to the question.

1. The task analysis of the Virabhadrasana II (Warrior II) is indicative of the original pose.

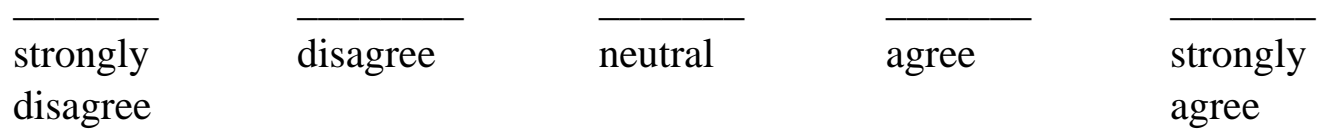

2. The task analysis of the Svanasana (Downward Facing Dog pose) is indicative of the original pose.

\begin{tabular}{|c|c|c|c|}
\hline strongly & disagree & neutral & agree \\
\hline
\end{tabular}

3. The task analysis of the Vriksasana (Tree pose) is indicative of the original pose.

\begin{tabular}{|c|c|c|c|}
\hline $\begin{array}{l}\text { strongly } \\
\text { disagree }\end{array}$ & disagree & neutral & agree \\
\hline
\end{tabular}

4. I believe the task analyses are easy to understand.

\begin{tabular}{|c|c|c|c|}
\hline $\begin{array}{l}\text { strongly } \\
\text { disagree }\end{array}$ & disagree & neutral & agree \\
\hline
\end{tabular}

5. I believe the task analyses are capable of testing the true form of a pose.

\begin{tabular}{|c|c|c|c|}
\hline $\begin{array}{l}\text { strongly } \\
\text { disagree }\end{array}$ & disagree & neutral & agree \\
\hline
\end{tabular}




\section{Appendix E: Participant Social Validity Rating Scales}

\section{Participant Rating Scale $1 \quad$ Participant \#}

Please carefully read and answer the six questions independently. Please make an $\mathbf{X}$ mark on the line that best indicates your opinion to the question.

1. I am comfortable performing the Virabhadrasana II (Warrior II pose).

\begin{tabular}{|c|c|c|c|}
\hline $\begin{array}{l}\text { strongly } \\
\text { disagree }\end{array}$ & disagree & neutral & agree \\
\hline
\end{tabular}

2. I am comfortable performing the Vriksasana (Tree pose).

\begin{tabular}{|c|c|c|c|}
\hline $\begin{array}{l}\text { strongly } \\
\text { disagree }\end{array}$ & disagree & neutral & agree \\
\hline
\end{tabular}

3. I am comfortable performing the Svanasana (Downward Facing Dog pose).

$\begin{array}{lllll}\overline{\text { strongly }} & \overline{\text { disagree }} & \overline{\text { neutral }} & \overline{\text { agree }} & \begin{array}{l}\text { strongly } \\ \text { agree }\end{array}\end{array}$

4. I liked using video feedback and the task analyses to self-manage my poses.

\begin{tabular}{|c|c|c|c|c|}
\hline $\begin{array}{l}\text { strongly } \\
\text { disagree }\end{array}$ & disagree & neutral & agree & $\begin{array}{l}\text { strongly } \\
\text { agree }\end{array}$ \\
\hline
\end{tabular}

5. I think my poses got better after using video feedback.

$\begin{array}{lllll}\overline{\text { strongly }} & \overline{\text { disagree }} & \overline{\text { neutral }} & \overline{\text { agree }} & \begin{array}{l}\overline{\text { strongly }} \\ \text { agree }\end{array}\end{array}$

6. The video feedback took the same amount of time that I expected.

\begin{tabular}{|c|c|c|c|}
\hline $\begin{array}{l}\text { strongly } \\
\text { disagree }\end{array}$ & disagree & neutral & agree \\
\hline
\end{tabular}




\section{Participant Rating Scale $2 \quad$ Participant \#}

Please carefully read and answer the six questions independently. Please make an $\mathbf{X}$ mark on the line that best indicates your opinion to the question.

1. I am comfortable performing the Virabhadrasana II (Warrior II pose).

\begin{tabular}{|c|c|c|c|c|}
\hline $\begin{array}{l}\text { strongly } \\
\text { disagree }\end{array}$ & disagree & neutral & agree & $\begin{array}{l}\text { strongly } \\
\text { agree }\end{array}$ \\
\hline
\end{tabular}

2. I am comfortable performing the Vriksasana (Tree pose).

\begin{tabular}{|c|c|c|c|c|}
\hline $\begin{array}{l}\text { strongly } \\
\text { disagree }\end{array}$ & disagree & neutral & agree & $\begin{array}{l}\text { strongly } \\
\text { agree }\end{array}$ \\
\hline
\end{tabular}

3. I am comfortable performing the Svanasana (Downward Facing Dog pose).

$\begin{array}{lllll}\begin{array}{l}\text { strongly } \\ \text { disagree }\end{array} & \overline{\text { disagree }} & \overline{\text { neutral }} & \begin{array}{l}\text { strongly } \\ \text { agree }\end{array}\end{array}$

4. I liked using video feedback.

\begin{tabular}{|c|c|c|c|c|}
\hline $\begin{array}{l}\text { strongly } \\
\text { disagree }\end{array}$ & disagree & neutral & agree & $\begin{array}{l}\text { strongly } \\
\text { agree }\end{array}$ \\
\hline
\end{tabular}

5. I think my poses got better after using video feedback.

$\begin{array}{lllll} & \overline{\text { disagree }} & \overline{\text { neutral }} & \overline{\text { agree }} & \begin{array}{l}\text { strongly } \\ \text { agree }\end{array}\end{array}$

6. The video feedback took the same amount of time that I expected.

$\begin{array}{lllll} & \overline{\text { disagree }} & \text { neutral } & & \begin{array}{l}\text { agree } \\ \text { strongly } \\ \text { agree }\end{array}\end{array}$




\section{Appendix F: Observer Rating Scales}

\section{Rating Scale for Warrior II Pose}

Please carefully read and answer the six questions independently while watching the video. Please make an $\mathbf{X}$ mark on the line that best indicates your opinion to the question.

1. The participant performed the Virabhadrasana II (Warrior II pose) with high accuracy.

\begin{tabular}{|c|c|c|c|}
\hline $\begin{array}{l}\text { strongly } \\
\text { disagree }\end{array}$ & disagree & neutral & agree \\
\hline
\end{tabular}

2. The participant looked like an expert when performing the Virabhadrasana II (Warrior II pose).

\begin{tabular}{|c|c|c|c|}
\hline $\begin{array}{l}\text { strongly } \\
\text { disagree }\end{array}$ & disagree & neutral & agree \\
\hline
\end{tabular}

3. The participant seemed to understand the flow of the Virabhadrasana II (Warrior II pose).

$\begin{array}{lllll}\overline{\text { strongly }} & \overline{\text { disagree }} & \overline{\text { neutral }} & \overline{\text { agree }} & \begin{array}{l}\text { strongly } \\ \text { agree }\end{array}\end{array}$

4. The participant's body parts were in the correct places during the flow of the Virabhadrasana II (Warrior II pose).

\begin{tabular}{|c|c|c|c|}
\hline $\begin{array}{l}\text { strongly } \\
\text { disagree }\end{array}$ & disagree & neutral & agree \\
\hline
\end{tabular}

5. The participant began the pose in the correct position.

\begin{tabular}{|c|c|c|c|}
\hline $\begin{array}{l}\text { strongly } \\
\text { disagree }\end{array}$ & disagree & neutral & agree \\
\hline
\end{tabular}

6. The participant ended the pose in the correct position.

\begin{tabular}{|c|c|c|c|}
\hline $\begin{array}{l}\text { strongly } \\
\text { disagree }\end{array}$ & disagree & neutral & agree \\
\hline
\end{tabular}

Observer name:

Participant number:

Video number: 


\section{Rating Scale for Downward Facing Dog Pose}

Please carefully read and answer the six questions independently while watching the video. Please make an $\mathbf{X}$ mark on the line that best indicates your opinion to the question.

1. The participant performed the Svanasana (Downward Facing Dog pose) with high accuracy.

\begin{tabular}{|c|c|c|c|}
\hline $\begin{array}{l}\text { strongly } \\
\text { disagree }\end{array}$ & disagree & neutral & agree \\
\hline
\end{tabular}

2. The participant looked like an expert when performing the Svanasana (Downward Facing Dog pose).

$\begin{array}{lllll}\begin{array}{l}\text { strongly } \\ \text { disagree }\end{array} & \overline{\text { disagree }} & \text { neutral } & \text { agree } & \begin{array}{l}\text { strongly } \\ \text { agree }\end{array}\end{array}$

3. The participant seemed to understand the flow of the Svanasana (Downward Facing Dog pose).

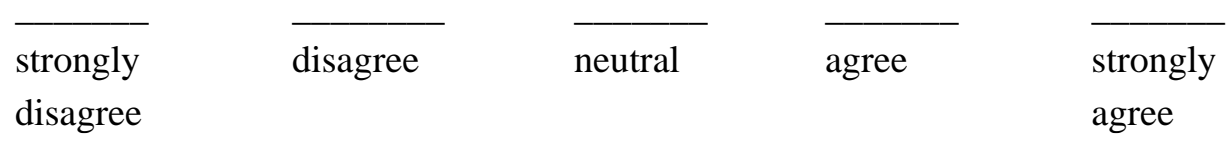

4. The participant's body parts were in the correct places during the flow of the Svanasana (Downward Facing Dog pose).

\begin{tabular}{|c|c|c|c|}
\hline $\begin{array}{l}\text { strongly } \\
\text { disagree }\end{array}$ & disagree & neutral & agree \\
\hline
\end{tabular}

5. The participant began the pose in the correct position.

$\begin{array}{lllll}\overline{\text { strongly }} & \overline{\text { disagree }} & \overline{\text { neutral }} & \overline{\text { agree }} & \begin{array}{l}\text { strongly } \\ \text { agree }\end{array}\end{array}$

6. The participant ended the pose in the correct position.

$\begin{array}{lllll}\overline{\text { strongly }} & \overline{\text { disagree }} & \overline{\text { neutral }} & \overline{\text { agree }} & \begin{array}{l}\text { strongly } \\ \text { agree }\end{array} \\ \text { disagree } & & & & \end{array}$

Observer name:

Participant number:

Video number: 


\section{Rating Scale for Tree Pose}

Please carefully read and answer the six questions independently while watching the video. Please make an $\mathbf{X}$ mark on the line that best indicates your opinion to the question.

1. The participant performed the Vriksasana (Tree pose) with high accuracy.

\begin{tabular}{|c|c|c|c|}
\hline $\begin{array}{l}\text { strongly } \\
\text { disagree }\end{array}$ & disagree & neutral & agree \\
\hline
\end{tabular}

2. The participant looked like an expert when performing the Vriksasana (Tree pose).

\begin{tabular}{|c|c|c|c|}
\hline $\begin{array}{l}\text { strongly } \\
\text { disagree }\end{array}$ & disagree & neutral & agree \\
\hline
\end{tabular}

3. The participant seemed to understand the flow of the Vriksasana (Tree pose).

$\begin{array}{lllll}\overline{\text { strongly }} & \overline{\text { disagree }} & \text { neutral } & \text { agree } & \begin{array}{l}\text { strongly } \\ \text { agree }\end{array}\end{array}$

4. The participant's body parts were in the correct places during the flow of the Vriksasana (Tree pose).

\begin{tabular}{|c|c|c|c|}
\hline $\begin{array}{l}\text { strongly } \\
\text { disagree }\end{array}$ & disagree & neutral & agree \\
\hline
\end{tabular}

5. The participant began the pose in the correct position.

$\begin{array}{lllll}\overline{\text { strongly }} & \overline{\text { disagree }} & \text { neutral } & \text { agree } & \begin{array}{l}\text { strongly } \\ \text { agree }\end{array}\end{array}$

6. The participant ended the pose in the correct position.

\begin{tabular}{|c|c|c|c|c|}
\hline $\begin{array}{l}\text { strongly } \\
\text { disagree }\end{array}$ & disagree & neutral & agree & $\begin{array}{l}\text { strongly } \\
\text { agree }\end{array}$ \\
\hline
\end{tabular}

Observer name:

Participant number:

Video number: 